\title{
Is RBM20 a Promising Target for HFpEF Therapy?
}

\author{
Wei Guo ${ }^{1,2 *}$ and Andrea R Sanchez Walk ${ }^{1,2}$ \\ ${ }^{1}$ Animal Science, University of Wyoming, Laramie, USA \\ ${ }^{2}$ Center for Cardiovascular Research and Integrative Medicine, University of Wyoming, USA,
}

Submission: April 23, 2017; Published: May 04, 2017

"Corresponding author: Wei Guo, Animal Science, University of Wyoming, Laramie, Center for Cardiovascular Research and Integrative Medicine, University of Wyoming, WY 82071, USA, Tel: +1 3077663429; Fax: +1 3077662355; Email: wguo3@uwyo.edu

Keywords: Titin isoform switching; Alternative splicing; HFpEF; RBM20

\section{Mini Review}

Heart Failure (HF) is a major public health issue with an estimated prevalence of over 37.7 million individuals worldwide [1], and remains the leading cause of morbidity, mortality, and hospitalization among adults and elderly [2,3]. In the USA, the total medical costs for patients with $\mathrm{HF}$ are expected to rise from US $\$ 20.9$ billion in 2012 to $\$ 53.1$ billion by 2030 [1]. About half of the patients with heart failure display preserved ejection fraction in contrast to the other half that present contractile dysfunction and a dilated heart (HF with reduced ejection fraction, HFrEF) [4,5]. Prototypical manifestations of heart failure with preserved ejection fraction (HFpEF), previously known as diastolic dysfunction, include increase in passive stiffness, insufficient recoil, and decrease in full relaxation [6]. Anaggregation of severalcontributors such as hypertension, metabolic syndrome, obesity and diabetes mellitus have been associated with the development of HFpEF [6]. Despite significant therapeutic improvements in the treatment of virtually all cardiac disorders, $\mathrm{HF}$ is an exception, in that its prevalence is rising, and its morbidity and mortality remain unacceptably high $[7,8]$. Currently, no effective therapies are available for HFpEF, at least with regard to major clinical events. Therefore, novel insights into pathophysiology and molecular mechanisms of HFpEF progression are required to develop novel therapeutic approaches.

Titin, as a major human disease gene, is emerging as a promising target for novel agents development for HFpEF therapy. Titin is a giant multi-functional sarcomeric filament withits $\mathrm{N}$-terminus embedded in the Z-disk of the sarcomere. The rest of the molecule is divided between an elastic I-band region, a thick filament-binding A-band region, and the $\mathrm{M}$-band region where the $\mathrm{C}$-terminus is embedded [9]. The extensible I-band region of titin functions as a molecular spring that develops passive force during diastole when sarcomeres are stretched [10] and endows the sarcomeres with long-range elasticity [11,12]. Titin has been well established as a main determinant of myocardial passive tension (PT), stiffness, and viscoelasticity $[6,13,14]$, together with the extracellular matrixbased collagen fibers [15]. The elastic properties of titin may support elastic recoil in early diastole [16] and early systolic shortening [17], which contributes to left ventricular filling. Therefore, manipulation of titin elasticity could be a strategy to adjust passive stiffness, and thus HFpEF therapy.

Titin, like most other proteins, undergoes protein turnover with half-life of three days in cardiac muscle [18], and posttranslational modifications. So far, two major mechanisms have been indicatedto adjust titin stiffness. They are titin isoform switching and phosphorylation by protein kinases such as PKA, PKG and PKC $[6,9,14,19]$. In this mini review article, we will give our opinion on the therapeutic potential of adjusting titin isoform switching in HFpEF.

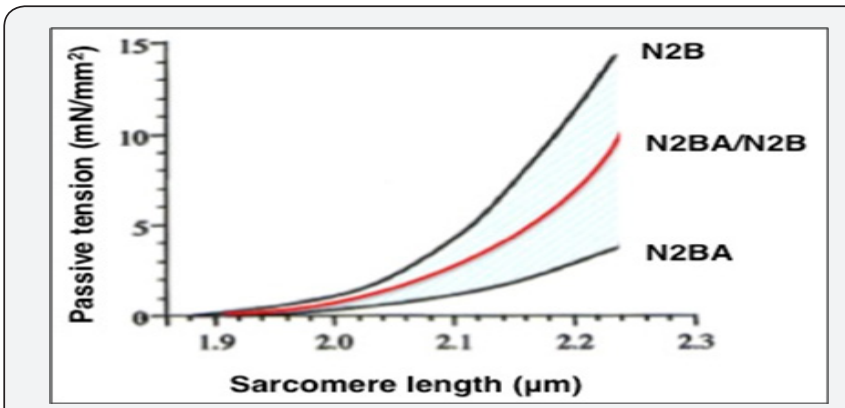

Figure 1: Relations between titin-based passive tension and sarcomere length. N2B expressing sarcomeres develop much higher passive tensions than N2BA expressing muscle. By coexpressing isoforms at varying ratios, an intermediate passive tension level can be observed

Titin produces two major isoform classes: N2BA and N2B resulting from alternative splicing. Different sizes of titin have distinct elastic properties. The smaller one, called N2B, is the stiffer isoform, and the larger one, called N2BA, is a more 
compliant isoform. At varying ratios of N2BA to N2B isoforms, the sarcomeres develop an intermediate level of passive tension (Figure 1) $[20,21]$ In normal human left ventricle (LV), the expression ratio of N2BA to N2B isoforms is about 30:70 [22]. However, in human patients, the altered titin isoform ratios have been detected. By comparing to non-failing donor heart, the larger and compliant N2BA levels was increased in ischemic cardiomyopathy [23], non-ischemic dilated cardiomyopathy (DCM) [24], and patients with HFrEF [25]. Overall, increased compliant N2BA isoforms can be commonly found in eccentric remodeled hearts with systolic dysfunction such as DCM, HFrEF and chronic ischemic cardiomyopathy, while reduced N2BA isoforms frequently can be observed in concentric remodeled hearts (compensated hypertrophy) with diastolic dysfunction developed from hypertensive heart disease. Therefore, manipulation of titin isoform ratios could be a potential therapeutic strategy for HFpEF therapy.

Recent studies indicated that RNA binding motif 20 (RBM20) is the major regulator of titin isoform switching in cardiac muscle [26,27]. Rbm20 knockout rats develop HFrEF with increased N2BA to N2B ratio [20]. Human hearts with a loss function of RBM20 in patients with HFrEF have an increased ratio of N2BA to N2B [28-31]. A couple very recent reports with mouse models of RBM20 manipulation showed the feasibility of such an approach. Reducing RBM20 levels in N2B knockout-induced diastolic dysfunction could improve diastolic stiffness [32] and inhibition of RBM20 in cardiac muscle can reduce ventricular wall stiffness induced in transverse aortic constriction (TAC) mouse model, and thus, improve diastolic function [33]. These studies suggest that adjusting RBM20 expression level could be an approach to adjust titin elasticity for HFpEF therapy. However, therapeutic modalities targeting RBM20 are currently largely theoretical due to still less-defined mechanism(s) of how RBM20 regulates titin isoform switching [34-40]. Therefore, future work should aim to address the detailed mechanisms of RBM20-mediated titin isoform switching. We believe that in the near future, RBM20 could be a real target to develop a novel therapeutic agent for HFpEF therapy [41].

\section{Acknowledgement}

This work was supported by the National Institute of Health/National Institute of General Medical Sciences (NIGMSP20GM103432); the BGIA from the American Heart Association (16BGIA27790136 to WG); the USDA National Institute of Food and Agriculture (Hatch project 1009266 to WG).

\section{References}

1. Ziaeian B, Fonarow GC (2016) Epidemiology and aetiology of heart failure. Nat Rev Cardiol 13(6): 368-378.

2. Hunt SA, Abraham WT, Chin MH, Feldman AM, Francis GS, et al. (2009) 2009 focused update incorporated into the acc/aha 2005 guidelines for the diagnosis and management of heart failure in adults. Circulation 119: e391-e479.
3. Von Lueder TG, Krum H (2015) New medical therapies for heart failure. Nat Rev Cardiol 12(12): 730-740.

4. Sequeira V, Nijenkamp LL, Regan JA, van der Velden J (2014) The physiological role of cardiac cytoskeleton and its alterations in heart failure. Biochim Biophys Acta 1838(2): 700-722.

5. Paulus WJ, van Ballegoij JJ (2010) Treatment of heart failure with normal ejection fraction: an inconvenient truth! J Am Coll Cardiol 55(6): 526-537.

6. Zile MR, Baicu CF, Ikonomidis JS, Stroud RE, Nietert PJ, et al. (2015) Myocardial stiffness in patients with heart failure and a preserved ejection fraction: contributions of collagen and titin. Circulation 131(14): 1247-1259.

7. Braunwald E (2013) Heart failure. JACC Heart Fail 1(1): 1-20.

8. Hilfiker-Kleiner D Landmesser U (2006) Molecular mechanisms in heart failure: focus on cardiac hypertrophy, inflammation, angiogenesis, and apoptosis. JACC 48(9): A56-A66.

9. Fürst DO, Osborn M, Nave R, Weber K (1988) The organization of titin filaments in the half-sarcomere revealed by monoclonal antibodies in immunoelectron microscopy: a map of ten nonrepetitive epitopes starting at the Z line extends close to the M line. J Cell Biol 106(5): 1563-1572.

10. Granzier HL, Irving TC (1995) Passive tension in cardiac muscle: contribution of collagen, titin, microtubules, and intermediate filaments. Biophys J 68(3): 1027-1044.

11. Maruyama K, Matsubara S, Natori R, Nonomura Y, Kimura S (1977. Connectin, an elastic protein of muscle: characterization and function. J Biochem 82(2): 317-37.

12. Wang K, McClure J, Tu (1979) Titin: major myofibrillar components of striated muscle. Proc Natl Acad Sci. U S A 76(8): 3698-702.

13. Yin Z, Ren J2, Guo W (2015) Sarcomeric protein isoform transitions in cardiac muscle: A journey to heart failure. Biochimica et Biophysica Acta 1852(1): 47-52.

14. Yamasaki R, Wu Y, McNabb M, Greaser M, Labeit S, et al. (2002) Protein kinase A phosphorylates titin's cardiac-specific N2B domain and reduces passive tension in rat cardiac myocytes Circ Res 90(11): 11811188.

15. Krüger M, Kötter S, Grützner A, Lang P, Andresen C, et al. (2009). Protein kinase G modulates human myocardial passive stiffness by phosphorylation of the titin springs. Circ Res 104(1): 87-94.

16. Helmes M, Trombitás K, Granzier H (1996) Titin develops restoring force in rat cardiac myocytes. Circ Res 79(3): 619-626.

17. Makarenko I, Opitz CA, Leake MC, Neagoe C, Kulke M, et al. (2004) Passive stiffness changes caused by upregulation of compliant titin isoforms in human dilated cardiomyopathy hearts. Circ Res 95(7): 708-716.

18. Isaacs WB, Kim IS, Struve A, Fulton AB (1989) Biosynthesis of titin in cultured skeletal muscle cells. J Cell Biol 109(5): 2189-2195.

19. Bartoo ML, Linke WA, Pollack GH (1997) Basis of passive tension and stiffness in isolated rabbit myofibrils. Am J Physiol 273(1 Pt 1): C266276.

20. Guo W, Bharmal SJ, Esbona K, Greaser ML (2010) Titin diversityalternative splicing gone wild. J Biomed Biotechnol 2010(2): 753675.

21. Zhu C, Chen Z, Guo W (2016) Pre-mRNA mis-splicing of sarcomeric genes in heart failure. Biochimica et Biophysica Acta 13(16): 3029030293.

22. Neagoe C, Kulke M, del Monte F, Gwathmey JK, de Tombe PP, et al. (2002) Titin isoform switch in ischemic human heart disease. Circulation, 106(11): 1333-1341. 
23. Opitz CA, Kulke M, Leake MC, Neagoe C, Hinssen H, et al. (2003). Damped elastic recoil of the titin spring in myofibrils of human myocardium. Proc Natl Acad Sci U S A 100(22): 12688-12693.

24. Nagueh SF, Shah G, Wu Y, Torre-Amione G, King NM, Lahmers S, et al. (2004) Altered titin expression, myocardial stiffness, and left ventricular function in patients with dilated cardiomyopathy. Circulation 110(2): 155-162.

25. Borbély A, Falcao-Pires I, van Heerebeek L, Hamdani N, Edes I, et al. (2009) Hypophosphorylation of the Stiff N2B titin isoform raises cardiomyocyte resting tension in failing human myocardium. Circ Res 104(6): 780-786.

26. Rampersaud E, Siegfried JD, Norton N, Li D, Martin E, et al. (2011) Rare variant mutation identified in pediatric patients with dilated cardiomyopathy. Prog Pediatr Cardiol 31(1): 39-47.

27. Methawasin M1, Hutchinson KR, Lee EJ, Smith JE, Saripalli C, et al (2014) Experimentally increasing titin compliance in a novel mouse model attenuates the frank-starling mechanism but has a beneficial effect on diastole. Circulation 129(19): 1924-1936.

28. Brauch KM, Karst ML, Herron KJ, de Andrade M, Pellikka PA. etal. (2009). Mutations in ribonucleic acid binding protein gene cause familial dilated cardiomyopathy. J Am Coll Cardiol 54(10): 930-41.

29. Millat G, Bouvagnet P, Chevalier P, Sebbag L, Dulac A, et al. (2011) Clinical and mutational spectrum in a cohort of 105 unrelated patients with dilated cardiomyopathy. Eur J Med Genet 54(6): e570-e575.

30. Refaat MM, Lubitz SA, Makino S, Islam Z, Frangiskakis JM, et al. (2012) Genetic variation in the alternative splicing regulator RBM20 is associated with dilated cardiomyopathy. Heart Rhythm 9(3): 390-396.

31. Wells QS, Becker JR, Su YR, Mosley JD, Weeke P, et al. (2013) Whole exome sequencing identifies a causal RBM20 mutation in a large pedigree with familial dilated cardiomyopathy. Circ Cardiovasc Genet 6(4): 317-26.

This work is licensed under Creative

Commons Attribution 4.0 License

DOI: $10.19080 /$ CTBEB.2017.03.555625
32. Hinze F, Dieterich C, Radke MH, Granzier H, Gotthardt M (2016) Reducing RBM20 activity improves diastolic dysfunction and cardiac atrophy. J Mol Med (Berl) 94(12): 1349-1358.

33. Methawasin M, Strom JG, Slater RE, Fernandez V, Saripalli C (2016) Experimentally increasing the compliance of titin through RNA binding motif-20 (RBM20) inhibition improves diastolic function in a mouse model of heart failure with preserved ejection fraction clinical perspective. Circulation 134(15): 1085-1099.

34. Li D, Morales A, Gonzalez-Quintana J, Norton N, Siegfried JD, et al. (2010). Identification of novel mutations in RBM20 in patients with dilated cardiomyopathy. Clin Transl Sci 3(3): 90-97.

35. Li S, Guo W, Dewey CN, Greaser ML (2013) Rbm20 regulates titin alternative splicing as a splicing repressor. Nucleic Acids Res 41(4): 2659-2672.

36. Linke WA (2008) Sense and stretchability: the role of titin and titinassociated proteins in myocardial stress-sensing and mechanical dysfunction. Cardiovasc Res 77(4): 637-648.

37. Linke WA, Popov VI, Pollack GH (1994) Passive and active tension in single cardiac myofibrils. Biophys J 67(2): 782-792.

38. Granzier HL, Labeit S (2004) The giant protein titin: a major player in myocardial mechanics, signaling, and disease. Circ Res 94(3): 284-295.

39. Guo W, Pleitner JM1, Saupe KW2, Greaser ML (2013) Pathophysiological defects and transcriptional profiling in the RBM20-/- rat model. Plos One 8(12): e84281.

40. Guo W, Schafer S, Greaser ML, Radke MH, Liss M et al. (2012). RBM20, a gene for hereditary cardiomyopathy, regulates titin splicing. Nat Med 18(5): 766-773.

41. Trombitás K1, Wu Y, Labeit D, Labeit S, Granzier H (2001) Cardiac titin isoforms are coexpressed in the half-sarcomere and extend independently. Am J Physiol Heart Circ Physiol 281(4): H1793-1799.

\section{Your next submission with Juniper Publishers will reach you the below assets}

- Quality Editorial service

- Swift Peer Review

- Reprints availability

- E-prints Service

- Manuscript Podcast for convenient understanding

- Global attainment for your research

- Manuscript accessibility in different formats

( Pdf, E-pub, Full Text, Audio)

- Unceasing customer service

Track the below URL for one-step submission https://juniperpublishers.com/online-submission.php 